\title{
QUALITY OF SEED PRODUCED BY TROPICAL FORAGE LEGUMES ON LOW FERTILITY SOILS
}

\author{
Andi L. Amar ${ }^{1)}$, Robert A. Congdon ${ }^{2)}$, Christopher P. Gardiner ${ }^{3)}$, Ross J. Coventry') \\ ${ }^{1)}$ Faculty of Animal Husbandry and fisheries. University of Tadulako. Palu. 94117 Central Sulawesi. Indonesia. \\ ${ }^{2)}$ School of Marine and Tropical Biolog James Cook University. Townsville. Queensland. 4811 Australia. \\ ${ }^{3)}$ School of Veterinary and Biomedical Science James Cook University. Townsville. Queensland. 4811Australia.
}

\begin{abstract}
Soil fertility can influence seed production and seedling growth. This study compared seed yields, seed and seedling characteristics of eight forage legumes (Stylosanthesscabra, S. hamata, Centrosemabrasilianum, C. pascuorum, Desmanthuspubescens, D. Virgatus, Macroptiliumbracteatum and M. martii) grown on two soil types (red and yellow kandosols), of low fertility, that are widespread in the Australian tropical rangelands. Seeds of the Desmanthus species germinated most rapidly and, with $M$. bracteatum, produced the highest proportion of readily germinable seed. $M$. bracteatum seed produced on the Yellow Kandosol germinated significantly faster, as did the $S$. hamata from the Red Kandosol than the other species. S. scabra cv. Seca and C. brasilianum produced more readily germinable seeds from plants grown on the Red Kandosol. C. pascuorum, $D$. pubescens and $M$. bracteatum produced a higher percentage of readily germinable seeds and fewer hard seeds when grown on the Yellow Kandosol. No significant differences were found in seedling vigour or biomass allocation from seeds produced on the different soil types.
\end{abstract}

Key Words : Fertility, forage, legumes, seed, soil, quality.

\section{INTRODUCTION}

It is well recognised that plant development and seed production are influenced by the surrounding environment. The environmental conditions during seed development, along with genetic characteristics and agronomic techniques have considerable effect on seed yield and components of yield through their effect on plant reproductive physiology (Martiniello, 1998). The quality of the seed sown, including its vigor, determines the success of the resulting plants; while seed quality is reflected in seedling density and vigor, uniformity of crop growth, and plants competitiveness, as well as forage production insome species (Hampton, 1995). Many publications have demonstrated that environmental experiences (e.g. light, nutrient, temperature, water,) of the maternal plant have influences on the performaces of the resulting progeny (Rossiter, 1996; Galloway, 2002; Etterson and Galloway, 2002; Galloway, 2005; Luzuriaga, et al., 2006; Galloway and Etteson, 2007; Uller, 2008; Wolf and Wade, 2009; Mitrovic, et al., 2010).

Nutrient supplies from the soil in which a plant grows is often found to be an important factor contributing to environment-induced maternal effects. Nutrient status of a plant may affect the number, size and quality of seeds produced, as well as the growth and competitive ability of the plants progeny (Aarssen and Burton 1990, Sills and Nienhuis 1995). This is in agreement with Miao et al. (1991a, 1991b) who showed that the maternal nutrient environment influences the competitive ability of progeny in Plantago spp.; and Galloway (2001) proved this with a strong effect of maternal nutrient environment on the germination of offspringin herbaceous plant Campanula americana. Though, this is not always the case. Luzuriaga, et al., (2006) found 
that added nitrogen to Sinapis arvensis plants only slightly reduced the germination rate of its seeds, but not the germination percentage.

A plant's ability to grow under certain conditions is not enough to indicate its ability to persist in an ecosystem for long periods, as is required for a pasture species. Production of a large number of seeds is an important factor controlling plant persistence, as is the seed's capacity to germinate, to provide new plants for regeneration. This is particularly important for an annual species whose persistence is strongly dependent on both seed production and viability. Furthermore, establishment of a good sward is also an important criterion for pasture production. Early seedling development plays an important role in the long-term growth of a plant, and in the dynamics of plant populations in the field (Hendrix 1984; Schmitt and Antonovics 1986). Several studies have demonstrated the importance of early emergence in relation to the competitive ability of the resulting seedlings (Crawley and Nachapong 1985; Dolan 1984).

Seeds resulting from a previous study entitled "an Early Growth Study" (Amar et al. 2012) were tested toinvestigate the effects of plant genotype and soil type on the performance of the progeny of the studied legumes. Although not as strong as genotype effects, it was found from the early study that the soil type significantly affected herbage yield, time to flowering and the number of seed produced (Amar et al., 2012). Therefore, it is hypothesised that edaphic influences on the parent plants may further affect the viability of the seeds produced and the performance of the resulting seedlings. Consequently, two experiments were conducted here, as a 'Germination Study' and a 'Seedling Study' which are described below.

The 'Germination Study' compared seed germination over time, the proportions of readily germinable seeds, hard seeds, and non-viable seeds resulting from the 8 legume genotypes grown on the different soils. The germination criteria, however, may not be sufficient to judge seed quality, since the readily germinable seeds might produce seedlings of different vigour, some of which may not result in an established plant. Therefore, a 'Seedling Study' was conducted to evaluate the characteristics of seedlings grown from seeds produced by the 5 legume genotypes that had been grown on the different soil types.

\section{MATERIALS AND METHODS}

\section{Germination Study.}

Experimental Design. The 'Germination Study' was carried out in a growth cabinet in the School of Marine and Tropical Biology, James Cook University, Townsville. The treatments considered 2 factors: the different legume genotypes (Amar et al., 2012), namely Stylosanthes, Centrosema, Desmanthus, and Macroptilium, and the different maternal backgrounds of the seeds, i.e. seeds of each of the legumes were collected from the plants grown on the different soils studied in the previous Early Growth Study (Amar et al., 2012). The numbers of seeds varied between genotypes because of the variation in numbers of seeds produced. The limited seed availability made it impossible to follow the standard procedure of the International Seed Test (ISTA 1985), therefore the method of Williams et al. (1992), who studied germination of small collections of Acacia seed, was adopted. The total number of seeds in each treatment combination (genotype - soil background) are listed in Table 1.

The 16 treatment combinations (8 plant genotypes $\times 2$ soil types of the maternal seed-producing plants) were arranged in a randomised block design with 6 replicates resulting in 96 experimental units.

Experimental Procedure. Before germination, the seeds were put into nylon-bags then immersed in water at $80^{\circ} \mathrm{C}$ for 5 minutes, except for the Stylosanthes scabra cv. Seca seeds, which were put into the water for 5 
minutes when the temperature dropped to $75^{\circ} \mathrm{C}$. Gilbert and Shaw (1979) found that Seca seeds achieved their highest germination percentage $(64 \%)$ when treated with water at $75^{\circ} \mathrm{C}$.

Seeds were placed in petri-dishes lined with filter paper following the international rules for seed testing guidelines (ISTA 1985), and modified by putting a layer of $2.5 \mathrm{~g}$ vermiculite under 3 layers of filter papers in each petri-dish. The petri-dishes were then arranged in a randomised block design with 6 replicates in a growth cabinet. The growth cabinet maintained a 12-hour light and dark regime intermittently every day, with a maximum temperature of 30 to $32^{\circ} \mathrm{C}$, a minimum temperature of 26 to $28^{\circ} \mathrm{C}$, and relative humidities of 64 to $72 \%$ and 74 to $84 \%$, for light and dark periods, respectively. The petri-dishes were kept moist for the duration of the study. The seeds were initially incubated for 4 weeks due to the very slow germination of some genotypes, particularly the Centrosema and Stylosanthes, which took up to the end of the fourth week to germinate. The seeds that had not germinated after 4 weeks were mechanically scarified by cutting the seed coat with a scalpel at the opposite end to the embryo. This was done to facilitate easy germination of hard seeds. The study was then continued for a further 10 days. By the end of the additional 10 day period, all the seeds that still had not germinated were considered to be non-viable.

A seed was considered to have germinated when it developed a radicle more than $3 \mathrm{~mm}$ long (Olff et al., 1994). The number of germinated seeds was recorded daily at midday and were removed from the petri-dishes. At the end of the study period, seeds were grouped into 3 categories: the 'readily germinable seeds' which germinated within 28 days; the 'hard seeds' that germinated after scarification of the seed coat (within 10 additional days), and the 'nonviable seeds' that did not germinate by the end of the experiment, and might comprise both 'dead' and 'empty' seeds according to (ISTA 1985) definitions. The last two were not differentiated in this study.

Seed quality was also determined by the time to $50 \%$ germination of the total number of readily germinable seeds (T50) using the formula of Coolbear et al. (1984):

$\mathrm{T} 50=\mathrm{t}_{\mathrm{i}}+\left\{0.5(\mathrm{~N}+1)-\mathrm{n}_{\mathrm{i}}\right\}\left\{\mathrm{t}_{\mathrm{j}}-\mathrm{t}_{\mathrm{i}}\right\} /\left\{\mathrm{n}_{\mathrm{j}}-\mathrm{n}_{\mathrm{i}}\right\}$

where:

T50 is time to $50 \%$ germination,

$\mathrm{N}$ is the final total number of readily germinable seeds, and

' $n_{i}$ ' and ' $n_{j}$ ' are the number of readily germinable seeds between two adjacent counts at times ' $t_{i}$ ' and ' $t_{j}$ ', where ' $n_{i}<$ $0.5(\mathrm{~N}+1)<\mathrm{n}_{\mathrm{j}} "$

Table 1. Germination Study: Treatments and The Number of Seeds Used. The Numbers of Seeds Were Not Uniform, Either Between Replicates or Between Soils, Due to Different Numbers of Available Seeds from Parent Plants

\begin{tabular}{|c|c|c|}
\hline \multirow{2}{*}{ Legume Genotypes } & \multicolumn{2}{|c|}{ No. of Seeds From Each Parent Plant Background } \\
\hline & Red Kandosol* & Yellow Kandosol* \\
\hline S. scabracv. Seca ${ }^{1}$ & 134 & 300 \\
\hline S. hamatacv. Verano & 390 & 390 \\
\hline C. brasilianum CPI $55698^{1}$ & 81 & 195 \\
\hline C. pascuorum CPI 55697 & 240 & 240 \\
\hline D.pubescens & 600 & 600 \\
\hline D. virgatus CPI 79653 & 600 & 600 \\
\hline M. bracteatum CPI 55770 & 330 & 330 \\
\hline M. martii CPI 55783 ${ }^{1}$ & 120 & 81 \\
\hline
\end{tabular}

Source: Cannon and Coventry (1989). 
Seedling Study.

Experimental Design. The study was conducted as an outdoor pot trial in the Genetic Garden of the School of Marine and Tropical Biology, James Cook University, Townsville. The pots were placed on mesh benches in a shade-free area.

This study examined seedlings grown from the same seed lot and experimental treatments as were used as in the 'Germination Study', except that fewer genotypes were involved (S. hamata cv. Verano, C. pascuorum, D. pubescens, D. virgatus CPI 79653, and M. bracteatum) because of the limited availability of seed. The 10 treatment combinations of 5 genotypes $\mathrm{x} 2$ soil types were arranged in a randomised block design with 6 replicates. All the data obtained from this study were subjected to an analysis of variance using a computer statistical package (Statistix version 4.1). Significant effects were then compared by least significant differences (LSD, $\mathrm{P}<0.05$ ).

Experimental Procedure. Seeds were scarified with hot water but not inoculated. A commercial topsoil, supplied by Flintstones Pty. Ltd. of Townsville, was passed through a $2 \mathrm{~mm}$ sieve, mixed thoroughly for homogeneity, and used to fill 60 experimental pots at $3.0 \mathrm{~kg}$ per pot on an oven-dry basis. The pots used were $17 \mathrm{~cm}$ high, with diameters of $16 \mathrm{~cm}$ (top) and $13 \mathrm{~cm}$ (bottom). The air-dry soil had $1.03 \%$ moisture content, and $2.90 \%$ organic matter on an oven-dry basis (determined from 3 soil samples). Single superphosphate was applied at an equivalent rate of $20 \mathrm{~kg}$ $\mathrm{P} / \mathrm{ha}$. The pots were saturated with water daily for 2 weeks before planting. This was done to make sure that all pots were well watered down to their bottom, as well as to allow any weed seeds in the soil to germinate and be removed prior to the experiment.

Six seeds were planted in each pot at no deeper than $1 \mathrm{~cm}$ deep. The pots were kept moist by watering every day during the study period.

Seedling emergence and vigour were scored (It is recognised that scoring seed and seedling vigour is difficult (ISTA 1985). within a legume genotype after 3 and 8 weeks by placing all the experimental units for the genotype together. The seedlings were ranked and scored in the following categories:

$0=$ Seedling did not emerge up to the end of the study period ( 8 weeks),

$1=$ Seedling emerged, but died during the initial 3-week period,

$2=$ Seedling emerged after the third week (weeks 4, 5, 6, 7 and 8), recording continued to the completion of the study,

$3=$ Treatment produced weak small seedlings (lowest rank among the living seedlings, within the same genotype) at the end of the third week,

$4=$ Healthy seedlings, with intermediate rank compared to the others of the same genotype, at the end of the third week and

$5=$ Vigorous seedlings, which fell into the highest rank among the same genotype, at the end of the third week.

After each scoring procedure, the pots were returned to their original positions in the randomised blocks. The seedling vigour of each pot was calculated as the mean for the 6 seeds. After week 3, the plants in each pot were thinned to a maximum of 3 plants/pot. C. Pascuorum and Verano, which produced less than 3 seedlings per pot, were thinned to 1 plant/pot. For the other genotypes, it was possible to follow the protocol of Sorensson et al. (1994) of discarding the smallest and largest seedlings from each pot and maintaining 3 intermediatesized plants. The emergence of additional seedlings was recorded weekly and any newly emerged seedlings were removed.

After 8 weeks, all the plants were cut off at the soil surface to measure shoot production, and the roots were collected by washing the contents of each pot through a $2 \mathrm{~mm}$ sieve to remove soil. Root nodulation was scored by the numbers of nodules produced as follows:

$0=$ nil nodules produced,

$1=1-5$ nodules produced, 
$2=6-10$ nodules produced,

$3=11-15$ nodules produced,

$4=16-20$ nodules produced, and

$5=$ more than 20 nodules produced.

All shoot and root biomass samples

were bagged, labelled, and dried in a forced-draught oven at $70^{\circ} \mathrm{C}$ to a constant weight for dry matter yield determination.

\section{RESULTS AND DISCUSSION}

Germination Study. All the observed plant parameters were significantly affected by legume genotype, while daily seed germination was the only attribute affected by soil type. However, significant interactions between legume genotype and soil type occurred for all measured plant attributes.

\section{Effects of The Interaction Between} Legume Genotype and Soil Type-on Seed Germination Over Time. Germination of the seeds of Stylosanthes and Centrosema was slow (Figure1 a and b). In contrast, seeds of the Desmanthus genotypes showed the quickest germination over time and the highest readily germinable seed percentages (Figure 1c). Intermediate seed germination times were recorded for Macroptilium (Figure 1d).

Figure 1 also shows differences among the legumes in terms of germination of the seeds produced by the maternal plants grown on the different soils (i.e. a genotype $\mathrm{x}$ soil interaction). Firstly, the seeds of Stylosanthes cultivars, Centrosema species, and D. Pubescens were not influenced during the first week of germination by the soil on which the parent plants were grown, after which each showed significantly different responses to the soil type (Figures 1a-c). These genotypes can be divided into two subgroups, namely: (i) seeds that germinated better when produced on the Red Kandosol, namely cv. Seca, cv. Verano and $C$. brasilianum; and (ii) seeds that germinated better when produced on the Yellow Kandosol, namely $C$. pascuorum, and D. pubescens. Secondly, the seeds of
D. virgatus CPI 79653 grown on the Red Kandosol germinated faster than those from plants on the Yellow Kandosol in the first-half of the germination period, after which there was no difference in the germination of the remaining seeds (Figure 1c). Thirdly, the seeds of $M$. bracteatum from parents grown on the Yellow Kandosol gave better germination than those from the Red Kandosol throughout the germination period (Figure 1d). Fourthly, there was no difference in germination behaviour between $M$. martii seeds from the Red and Yellow Kandosols (Figure 1d).

Each of the times to $50 \%$ germination of the total readily germinable seeds (Coolbear et al., 1984, Pasumarty et al., 1995) shown in Table 2 excludes the additional germination period after the seed coats of the non-readily germinated seeds were cut. Seeds of the Stylosanthes and Centrosema species showed a slow germination rate, needing 13 to 17 days to produce $50 \%$ of readily germinable seeds, whether produced on the Red or Yellow Kandosol. D. virgatus CPI 79653 seeds produced on the Red Kandosol were the fastest to $50 \%$ germination, while those of $M$. bracteatum were the fastest from plants grown on the Yellow Kandosol.

Three trends among the legume genotypes can be identified for the time to $50 \%$ germination of their readily germinable seeds. Most of them (6 genotypes: namely Seca, the Centrosema, Desmanthus and $M$. martii) showed no difference between seeds produced on the different soil types. S. hamata cv. Verano seeds from the Red Kandosol germinated more quickly, but those of $M$. bracteatum from the Yellow Kandosol germinated faster (Table 2).

Effects of the Interaction Between Legume Genotype and Soil Type-on Seed Viability. The numbers of viable seeds (readily germinable seeds and hard seeds), and nonviable seeds were strongly controlled by legume genotype, and there were significant interactions between genotype and soil type (Table 3). 

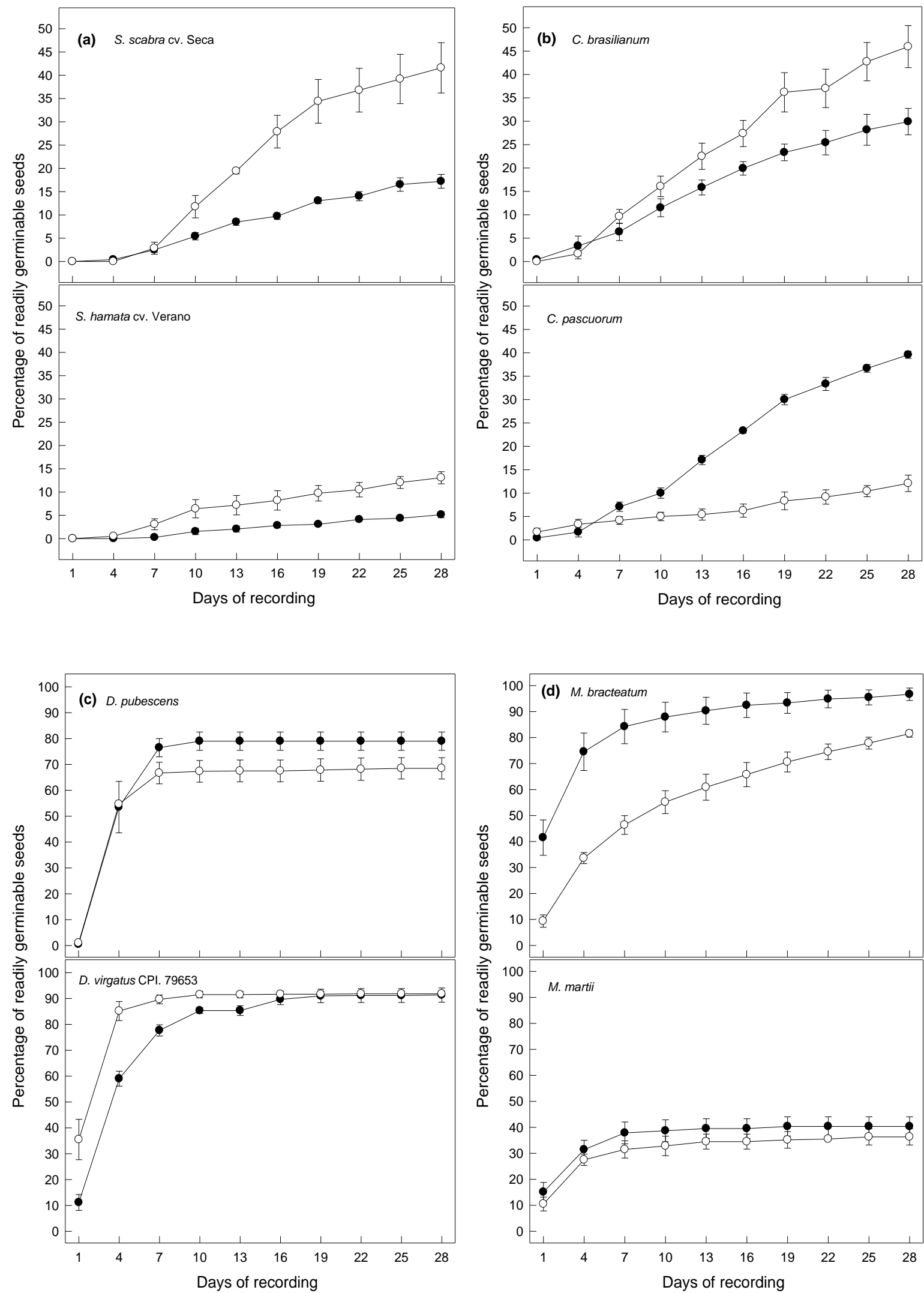

Figure 1. Germination Rates for Seeds of (a) Stylosanthes, (b) Centrosema, (c) Desmanthus, and (d) Macroptilium Genotypes Resulting from Plants Grown on Red (o) and Yellow (•) Kandosol Soils $(\mathrm{n}=6)$. Error Bars = Standard Errors. 
Table 2. Germination Study: Comparison of Mean Time (Days) to 50\% Germination of Seeds Produced by Pasture Legumes Grown on Different Kandosol Soils. Means in a Column Followed by The Same Lower Case Letter are Not Significantly Different. Means in a Row Followed by Different Upper Case Letters are Significantly Different

\begin{tabular}{lcc}
\hline \multirow{2}{*}{ Gegume } & \multicolumn{2}{c}{ Soil Types } \\
\cline { 2 - 3 } & Red Kandosol & Yellow Kandosol \\
\hline S. scabra cv. Seca & $14.6 \mathrm{a}$ & $15.0 \mathrm{ab}$ \\
S. hamata cv. Verano & $14.1 \mathrm{aB}$ & $17.3 \mathrm{aA}$ \\
C. brasilianum CPI 55698 & $14.5 \mathrm{a}$ & $12.8 \mathrm{~b}$ \\
C. pascuorum CPI 55697 & $14.1 \mathrm{a}$ & $14.4 \mathrm{ab}$ \\
D. pubescens & $2.6 \mathrm{~d}$ & $3.2 \mathrm{c}$ \\
D. virgatus CPI 79653 & $1.3 \mathrm{~d}$ & $2.6 \mathrm{c}$ \\
M. bracteatum CPI 55770 & $6.8 \mathrm{bcA}$ & $1.9 \mathrm{cB}$ \\
M. martii CPI 55783 & $3.7 \mathrm{~cd}$ & $3.1 \mathrm{c}$ \\
\hline s.e. & & \\
\hline
\end{tabular}

D. virgatus CPI 79653 and $M$. bracteatum produced the highest percentages of readily germinable seeds from plants grown on either soil type (Table 3a). D. pubescens also produced a high proportion of readily germinable seeds, while all the other genotypes had less than 50\% readily germinable seeds. S. scabra cv. Seca and $C$. brasilianum produced more readily germinable seeds when grown on the Red Kandosol, in contrast to C. pascuorum, $D$. pubescens and $M$. bracteatum. The other 3 genotypes produced similar proportions of readily germinable seeds from either soil.

$S$. hamata cv. Verano had the highest proportion of hard seeds on both soils followed by $C$. pascuorum, $S$. scabra cv. Seca and $C$. brasilianum (Table 3b). This shows the well known hard seededness of these legumes (see for example English and Hopkinson, 1985; Hopkinson and Paton, 1993). M. martii also had a relatively high proportion of hard seeds on both soils. The Desmanthus genotypes and $M$. bracteatum had some what lower hardseededness, but $D$. Pubescens produced almost $30 \%$ hard seeds when grown on the Red Kandosol. C. pascuorum, D. Pubescens and both Macroptilium species produced a greater proportion of hard seeds on the Red Kandosol than on the Yellow Kandosol, in contrast to Seca and C. brasilianum. The proportions of hard seeds of S. Hamata cv. Verano and D. Virgatus CPI 79653 were not significantly influenced by the different soils.

Most of the legumes had a low proportion of non-viable seeds, except for $20 \%$ of the seeds of $M$. martii produced on the Yellow Kandosol (Table 3c). Verano was the only genotype to produce $100 \%$ viable seeds (i.e. $0 \%$ non-viable seed, Table 3c), followed by C. pascuorum, Seca, and $M$. bracteatum, all of which produced more than $99 \%$ viable seeds.

Seedling Study. Legume genotype had highly significant effects on all of the seedling parameters, but none of the parameters were significantly influenced by either soil type or genotype $\mathrm{x}$ soil type interactions. $M$. Bracteatum had the highest seedling vigour followed by $D$. virgatus CPI 79653 and D. pubescens, and the lowest was recorded for Verano and C. pascuorum (Table 4). Seedlings of C. pascuorum, Verano, and M. Bracteatum produced a consistently higher biomass and better root nodulation than Desmanthus genotypes (Tables 4 and 5). Verano had the highest seedling shoot: root ratio, followed by $C$. pascuorum, both Desmanthus genotypes, and $M$. Bracteatum (Table 5). The low score for root nodulation of Desmanthus suggests that either the Desmanthus genotypes are slow to nodulate, or they need a specific rhizobium inoculation. 
Most of the differences observed in seed germination and seedling establishment characteristics of plants whose parents were grown in different soils were due to genotypic differences, with the soil type of the parent plants playing a minor role. Nevertheless, the germination study showed that Verano seed produced on yellow kandosol germinated significantly faster than those resulting from plants on red kandosol; and significant response was also evidence from seeds of $M$. bracteatum but riversed with Verano seed response, while other species did not response significatly (Table 2). This finding indicates the different sensitivities among the studied legume genotypes to the slight different of both soil where the parent plants were grown. Though, more studies are necessary to confirm this result. Studies on different plants, Miao et al. (1991a, 1991b) on Plantago spp.; Galloway (2001) on Campanula Americana, and Luzuriaga, et al. (2006) on Sinapis arvensis, have suggested varieties of different genotypes respond to different enviromental factors, and to an enviromental factor at different in levels of intensity. Such sensitivity responses have been identified in some topical forage legumes grown on various harsh condition (Agronomic Sensitivity Index; Amar., 1996).

Table 3. Germination Study: Comparisons of Mean Seed Viability of Seeds from The Legumes Grown on Different Soil Types ( $\mathrm{n}=6$ ). Means in a Column Followed by The Same Lower Case Letter Do Not Differ Significantly. Means Followed by Different Upper Case Letters Within a Row, Within The Same Seed Attribute, Are Significantly Different

\begin{tabular}{|c|c|c|c|c|c|c|}
\hline & \multicolumn{2}{|c|}{$\begin{array}{l}\text { (a) Readily germinable } \\
\text { seeds }(\%)\end{array}$} & \multicolumn{2}{|c|}{$\begin{array}{l}\text { (b) Hard seeds } \\
\text { (\%) }\end{array}$} & \multicolumn{2}{|c|}{$\begin{array}{l}\text { (c) Non-viable seeds } \\
(\%)\end{array}$} \\
\hline & $\begin{array}{l}\text { Red } \\
\text { Kandosol }\end{array}$ & $\begin{array}{l}\text { Yellow } \\
\text { Kandosol }\end{array}$ & $\begin{array}{l}\text { Red } \\
\text { Kandosol }\end{array}$ & $\begin{array}{l}\text { Yellow } \\
\text { Kandosol }\end{array}$ & $\begin{array}{l}\text { Red } \\
\text { Kandosol }\end{array}$ & $\begin{array}{l}\text { Yellow } \\
\text { Kandosol }\end{array}$ \\
\hline S. scabracv. Seca & $41.3 \mathrm{~d} \mathrm{~A}$ & 17.2 e B & $58.6 \mathrm{bD}$ & 81.9 b C & $0.1 \mathrm{c}$ & $0.8 \mathrm{~b}$ \\
\hline S. hamatacv. Verano & $13.1 \mathrm{e}$ & $5.1 \mathrm{f}$ & 86.9 a & $94.9 \mathrm{a}$ & $0.0 \mathrm{c}$ & $0.0 \mathrm{~b}$ \\
\hline C. brasilianum & $46.0 \mathrm{~d} A$ & $29.9 \mathrm{~d} \mathrm{~B}$ & 44.9 c D & 68.4 c C & $9.2 \mathrm{a} \mathrm{E}$ & $1.7 \mathrm{~b} \mathrm{~F}$ \\
\hline C. pascuorum & 12.1 e B & $39.6 \mathrm{~cd} \mathrm{~A}$ & 87.5 a C & $60.0 \mathrm{c} \mathrm{D}$ & $0.4 \mathrm{c}$ & $0.4 \mathrm{~b}$ \\
\hline D. pubescens & $68.5 \mathrm{c} \mathrm{B}$ & $79.0 \mathrm{~b} \mathrm{~A}$ & $28.5 \mathrm{~d} \mathrm{C}$ & 15.7 e D & $3.0 \mathrm{bc}$ & $5.3 \mathrm{~b}$ \\
\hline $\begin{array}{l}\text { D. virgatus CPI } \\
79653\end{array}$ & $91.8 \mathrm{a}$ & $91.3 \mathrm{a}$ & $6.7 \mathrm{e}$ & 8.2 efd & $1.5 \mathrm{c}$ & $0.5 \mathrm{~b}$ \\
\hline M. bracteatum & 81.5 b B & $96.7 \mathrm{aA}$ & $17.6 \mathrm{dC}$ & $3.3 \mathrm{fD}$ & $0.9 \mathrm{c}$ & $0.0 \mathrm{~b}$ \\
\hline M. martii & $36.3 \mathrm{~d}$ & $40.4 \mathrm{c}$ & $56.5 \mathrm{~b} \mathrm{C}$ & $39.6 \mathrm{~d} \mathrm{D}$ & $7.2 \mathrm{ab} \mathrm{F}$ & $20.0 \mathrm{a} \mathrm{E}$ \\
\hline s.e. & 4.79 & & 5.42 & & 2.78 & \\
\hline
\end{tabular}

Table 4. Seedling Establishment Study: Comparison of Means of The Seedling Vigour and Biomass Resulting From Seeds of Different Legumes $(n=6)$. Means in a Column Followed by The Same Lower Case Letter Do Not Differ Significantly

\begin{tabular}{lcccc}
\hline Legume & Seedling & \multicolumn{4}{c}{ Seedling Dry-matter (g/plant) } \\
\cline { 3 - 5 } Genotypes & Vigour & Shoot & Root & Total \\
\hline S. hamata cv. Verano & $1.49 \mathrm{c}$ & $1.47 \mathrm{a}$ & $0.48 \mathrm{c}$ & $1.95 \mathrm{a}$ \\
C. pascuorum CPI 55697 & $1.43 \mathrm{c}$ & $1.74 \mathrm{a}$ & $0.66 \mathrm{a}$ & $2.41 \mathrm{a}$ \\
D. pubescens & $3.15 \mathrm{~b}$ & $0.29 \mathrm{c}$ & $0.16 \mathrm{~d}$ & $0.44 \mathrm{c}$ \\
D. virgatus CPI 79653 & $3.42 \mathrm{~b}$ & $0.27 \mathrm{c}$ & $0.14 \mathrm{~d}$ & $0.40 \mathrm{c}$ \\
M. bracteatum CPI 55770 & $4.33 \mathrm{a}$ & $0.77 \mathrm{~b}$ & $0.60 \mathrm{bc}$ & $1.37 \mathrm{~b}$ \\
\hline s.e. & 0.24 & 0.22 & 0.07 & 0.28 \\
\hline
\end{tabular}


Table 5. Seedling Establishment Study: Comparison of Means of The Seedling's Root Parameters Resulting from Seeds of Different Legumes $(n=6)$. Means in a Column Followed by The Same Lower Case Letter Do Not Differ Significantly

\begin{tabular}{lcc}
\hline $\begin{array}{l}\text { Legume } \\
\text { Genotypes }\end{array}$ & $\begin{array}{l}\text { Shoot : root } \\
\text { Ratio }\end{array}$ & $\begin{array}{l}\text { Nodulation } \\
\text { Score }\end{array}$ \\
\hline S. hamata cv. Verano & $2.92 \mathrm{a}$ & $5.00 \mathrm{a}$ \\
C. pascuorum CPI 55697 & $2.60 \mathrm{~b}$ & $4.92 \mathrm{ab}$ \\
D. pubescens & $1.85 \mathrm{c}$ & $0.92 \mathrm{c}$ \\
D. virgatus CPI 79653 & $1.98 \mathrm{c}$ & $0.75 \mathrm{c}$ \\
M. bracteatum CPI 55770 & $1.30 \mathrm{~d}$ & $4.67 \mathrm{~b}$ \\
\hline s.e. & 0.12 & 0.16 \\
\hline
\end{tabular}

The low numbers of readily germinable seeds and the high hard seed percentages of the stylos have been well documented previously (see for example, English and Hopkinson, 1985; Hopkinson and Paton, 1993). A significant number of hard seeds may rapidly accumulate in the soil seed bank of the annual-biennial Veranoin rangeland paddocks, and provides a mechanism to ensure plant persistence and continuity of herbage production even if seed is not produced in some years (Gutteridge 1985, Mott et al., 1989). In swards of perennial stylos (S. scabra and S. viscosa), however, the long-term stability of the pasture was found to depend on the survival of perennating plants that contributed $80 \%$ of the yield (Mott et al., 1989).

The high germination percentage of D. pubescens and D. virgatus (68\% to $92 \%)$ is supported by Luckow (1993) who showed a wide range of Desmanthus species to have germination percentages ranging from $53 \%$ to $100 \%$. The results of the current study indicate that plants of these genotypes can produce abundant viable seeds when grown on Red and Yellow Kandosol soils. Since both of these genotypes are perennial, it is also possible that plant persistence depends on similar strategies to those of the perennial stylos, such as long-lived plants of $S$. guianensis, S. scabra, and S. viscosa (Miles et al., 1994, Mott et al. 1989), which include the deep root system and resistance to heavy grazing of S. scabra (Cameron 1988, Miles et al., 1994, Partridge et al., 1996).
Similarly, the high germination percentage of the perennial $M$. bracteatum seeds $(81 \%-97 \%)$, and low percentage of readily germinable seed for the annual M. martii seeds $(36 \%$ - 40\%) may reflect similar plant persistence strategies to those of Stylosanthes. That is, a high proportion of hard seeds of short-lived plants such as $M$. martii provides an effective seed supply to soil seed banks for long-term persistence of the genotype. The persistence of the perennial $M$. bracteatum is more likely to be dependent on long-lived surviving plants.

Unlike Stylosanthes and Macroptilium, both the perennial $C$. brasilianum and annual $C$. pascuorum produced a low proportion of readily germinable seeds. This suggests that long-term persistence of the Centrosema species is maintained by accumulation of hard seeds in the soil. However, it was found that $C$. brasilianum produced a low number of seeds (Amar et al., 2012). Therefore, long-lived plants are still required to ensure continuity of herbage production from this species. A large quantity of seeds produced and a high proportion of viable seeds are important for plant persistency in pastures. On the other hand, a seed lot with a high proportion of non-viable seeds is not favourable for pasture species. Nevertheless, there are many other determining factors for plant persistence, for example grazing resistance, competitive ability, and compatibility with other pasture species or crops. 
The interaction between genetic and edaphic factors indicates differences among the legume genotypes in germination rates in response to the different soils. These are shown by the shorter time to $50 \%$ germination of the seeds of $M$. bracteatum grown on the Yellow Kandosol, and by Verano seeds from the Red Kandosol. The other genotypes showed no such soilrelated differences. The strong response of $M$. bracteatum on the Yellow Kandosol, however, is difficult to explain.

All of the legume genotypes produced a high proportion of viable seeds, though M. martii had $20 \%$ non-viable seeds on the Yellow Kandosol (Table 3). Considering the total numbers of viable seeds, the Desmanthus genotypes and $M$. bracteatum produced high proportions of readily germinable seeds, while the Centrosema species, Stylosanthes cultivars and $M$. martii produced high proportions of hard seeds. Hardseededness is well recognised as a characteristic commonly possessed by leguminous seeds, up to $90 \%$ in some species, resulting in variable germination (Harty 1996). Skerman et al. (1988) and Ferguson et al. (1990) found that the proportion of hard seeds in Centrosemapubescens is high (33\% to $50 \%)$. Compared with this, C. brasilianum and $C$. pascuorum had a very high proportion of hard seeds in the present study (45-68\% and $60-87 \%$, respectively; Table 3).

The Desmanthus species were found to have a high seed germination (low hardeseededness). Hardeseededness isa common feature of leguminous plants that possess an impermeable seed coat (Harty 1996, Hopkinson and Paton 1993). However, the Desmanthus has different seed structures to other legume species, the hilum is less distinct, the strophiole erupts rather than cleaving and a plug of tissue is ejected (Dell 1980), which may facilitate water entry into the seed rather than through an impermeable seed-coat. Hopkinson and Paton (1993) pointed out that this seed structure can easily be seen under a magnifier after hot water treatment in seeds of $D$. virgatus, Cassia rotundifolia, and Leucaenaleucocephala. Rangel and Gardiner (1994) showed that the strophiole in fresh seeds, and the slightly raised, fully raised and raised but broken strophiole of D. virgatus seeds, are permeable to water. This suggests that it would be interesting to omit any seed treatment for the first germination period to determine readily germinable seeds in similar studies.

Macroptilium, Stylosanthes, and Centrosema all belong to the family Fabaceae, whose members generally have hard seed coats, and therefore high proportions of hard seeds. M. atropurpureum cv. Siratro, for example, has $40 \%$ to $70 \%$ of hard seeds (Skerman et al. 1988). This was also shown for $M$. martii in the present study (40\%-57\% hard seeds; Table 3). Surprisingly however, $M$. bracteatum produced a low proportion $(3 \%-18 \%)$ of hard seeds, similar to $D$. virgatus. This suggests that seeds of $M$. bracteatum may also have a different structure, or a different composition of the seed coat that make the seeds more permeable to water.

The Red and Yellow Kandosol soils induced differences in legume responses in which three main trends can be identified:

a) S. scabra cv. Seca and C. brasilianum produced a higher percentage of readily germinable seeds from plants grown on the Red Kandosol. Fewer hard seeds were produced by $C$. brasilianum when grown on the Red Kandosol where it also produced a higher proportion of nonviable seed.

b) C. pascuorum, D. pubescens and $M$. bracteatum produced a higher percentage of readily germinable seeds and fewer hard seeds when grown on the Yellow Kandosol. There was no significant difference in the proportion of non-viable seeds between the soils.

c) Soil type did not affect the proportion of readily germinable seeds of $S$. Hamata cv. Verano, D. virgatus CPI 79653 and 
M. martii. M. martii, however, produced more hard seeds but fewer non-viable seeds from the plants grown on the Red Kandosol.

Some differences in seed germination characteristics are evident between soils for some genotypes, but the differences diminished as the seedlings began to establish. These results imply that environmental impacts on a parent plant, such as different soils, may affect the plant progeny but the effect decreases with the further growth of the resulting progeny. The effects would probably last longer into the subsequent growth stages of the plant progeny if the controlling factors were more significantly different, and induced more extreme effects on the parent plants and the seeds they produce. This hypothesis is supported by previous studies where environmental effects on a parent plant were found to have influences on numbers of seeds produced (Dolan 1984), seed germination (Sills and Nienhuis 1995), seedling growth, competitive ability and establishment, and were even still apparent on the biomass of adult progeny (Crawley and Nachapong 1985; Schmitt and Antonovics 1986).

\section{CONCLUSION}

The 5 legume genotypes showed systematic differences in seedling vigour and seedling characteristics. The genotypes producing the highest percentage of readily germinable seeds, $M$. bracteatum and both of the Desmanthus accessions, also had a high seedling vigour which may have a major influence on plant behaviour and persistence in the field.

Consistent differences were found in seedling biomass among the legume genotypes. The seedlings of Verano and $C$. pascuorum produced the highest biomass followed by the seedlings of $M$. bracteatum, then those of the Desmanthus genotypes. No differences in any of the seedling parameters could be attributed to soil type. The results of this study suggest that seedling performance is strongly controlled by plant genotype.

Acknowledgements. The authors wish to thank Dr R.L. Burt for his advice at the initiation of this study. Australian Agency for International Development (Aus AID) provided financial support, and the Derectorate General of Higher Education of the Republic Indonesia for the support given for this publication, are appreciated.

\section{REFERENCES}

Aarssen, L. W. And Burton, S. M., 1990. Maternal Effects at Four Levels of Senecio Vulgaris (Asteraceae) Grown on a Soil Nutrient Gradient. American Journal of Botany. 77. 1231-1240.

Amar, A. L., 1996. Responses of Tropical Forage Legumes to Soils of Low Fertility. Thesis Submitted for The Degree of Doctor of Philosophy in Tropical Plant Sciences within The School of Tropical Biology. James Cook University. Australia.

Amar, A. L., Coventry, R., Congdon, R. A. and Gardiner, C. P., 2012. Performance of Tropical Forage Legumes on Low Fertility Soils: An Early Growth Study. Agrisains, 13/1: 1 - 12.

Cameron, D. G., 1988. Tropical and Subtropical Pasture Legumes. 16. Shrubby Stylo (Stylosanthes Scabra): The Dry Tropics Perennial Browse. Queensland Agricultural Journal. 114. 105-109.

Cannon, M.G. And Coventry, R.J., 1989. Soils of The CSIRO Experimental Area, 'Redlands', Balfes Creek, North Queensland. Divisional Report. 99. Division of Soils. CSIRO Australia.

Coolbear, P., Francis, A.AndGrierson, D., 1984. The Effect of Low Temperature Pre-Sowing Treatment on The Germination Performance and Membrane Integrity of Artificial Aged Tomato Seeds. Journal of Experimental Botany. 35. 1609-1617. 
Crawley, M. J. and Nachapong, M., 1985.The Establishment of Seedlings from Primary and Regrowth Seeds of Ragwort (Senecio Jacobea). Journal of Ecology. 73. 255-261.

Dell, B., 1980. Structure and Function of The Strophiolar Plug in Seed of Albizia Lophantha. American Journal of Botany. 67. 556-563.

Dolan, R. W., 1983. The Effect of Seed Size and Maternal Source on Individual Size in A Population of Ludwigia Leptocarpa (Onagraceae). American Journal of Botany. 71. 1302-1307.

English, G. H. And Hopkinson, J. M., 1985. Verano Stylo Seed Production. Queensland Agricultural Journal. 111. 59-63.

Ferguson, J. E., Hopkinson, J. M., Humphreys, L. R. and De Andrade., R. P., 1990. Seed Production of Centrosema Species. In: Schultze-Kraft, R. and Clements. R.J. (ed.) Centrosema: Biology. Agronomy. and Utilization.pp. 221-244. (CIAT: Cali, Colombia.).

Galloway, L. F., 2001. Parental Environmental Effects on Life History in The Herbaceous Plant. Campanula Americana. Ecology. 82: 2781-2789.

Galloway, L.F., 2002. The Effect of Maternal Phenology on Offspring Characters in The Herbaceous Plant Campanula Americana. Journal of Ecology. 90: 851-858.

Galloway, L.F., 2005. Maternal Effects Provide Phenotypic Adaptation to Local Environmental Conditions. New Phytologist.166: 93-100.

Gutteridge, R. C., 1985. Survival and Regeneration of Four Legumes Oversown Into Native Grasslands in Northeast Thailand. Journal of Applied Ecology. 22. 885-894.

Hampton, J.G., 1995. Herbage seed vigour. In: Proceedings of The Third International Herbage Seed Conference. Halle (Salle). Germany. June 18-23. pp. 465-468.

Harty, R. L. 1996. Seed testing. In: Partridge, I. (ed.) Tropical Pasture Seed Production - a Training Manual.pp. 71-76. Queensland Department of Primary Industries: Brisbane.

Hendrix, S. D., 1984. Variation in Seed Weight and Its Effects on Germination in Pastinaga Sativa L. (Umbelliferae). American Journal of Botany. 71. 795-802.

Hopkinson, J. M. and Paton, C. J., 1993. Tropical Pasture Establishment 6 Treatment of Seca Stylo Seed to Reduce Hard Seed Content. Tropical Grasslands. 27. 327-334.

Ista, 1985. International Rules for Seed Testing, Rules 1985. International Seed Testing Association (ISTA). Adopted at the Twentieth International Seed Testing Congress. Canada 1983. to become effective on July 1985. Seed Science and Technology. 13. 299-355.

Luckow, M., 1993. Monograph of Desmanthus (Leguminosae-Mimosoideae). Systematic Botany Monographs. Volume 38. The American Society of Plant Taxonomists. USA.

Luzuriaga.A.L., Escudero, A. and Pe'Rez-Garci'A, F., 2006. Environmental Maternal Effects on Seed Morphology and Germination in Sinapis Arvensis (Cruciferae). Weed Research. 46: 163-174.

Martiniello, P., 1998. Influence of Agronomic Factors on The Relationship Between Forage Production and Seed Yield in Perennial Forage Grasses and Legumes In A Mediterranean Environment. Agronomie. 18: 591-601.

MiaO, S.L., Bazzaz, F.A. And Primack, R.B., 1991a. Persistence of Maternal Nutrient Effects in Plantago Major: The Third Generation. Ecology. 72: 1636-1642.

Miao, S.L., Bazzaz, F.A. And Primack, R.B., 1991b. Effects of Maternal Nutrient Pulse on Reproduction of Two Colonizing Plantago Species. Ecology. 73: 586-596. 
Miles, J. W., Thomas, R. J., Lascano, C., Fisher, M. J., Vera, R. and Sanz, J. I., 1994. Evaluation of Stylosanthes for Selected Farming Systems of Tropical America. In: de Leeuw, P. N., MohamedSaleem, M. A. and Nyamu, A. M. (ed.) Stylosanthes as a Forage and Fallow Crop. Proceedings of The Regional Workshop on The Use of Stylosanthes in West Africa. Held in Kaduna. Nigeria. 26-31 October 1992. pp. 25-33. (ILCA: Addis Ababa. Ethiopia).

Mitrovic, A., Bogdanovic, J., Giba, Z. And Culafic, L., 2010. Effect of Photoperiod During Growth of Chenopodium Rubrum Mother Plants on Properties of Offspring. Biologia Plantarum. 54 (4): 735739. 2010.

Mott, J. J., Winter, W. H and Mclean, R. W., 1989. Management Options for Increasing The Productivity of Tropical Savanna Pastures IV. Population Biology of Introduced Stylosanthes Spp. Australian Journal of Agricultural Research. 40. 1227-1140.

Olff, H., Pegtel, D., Van Groenendael. J. M. and Bakker, J.P., 1994. Germination Strategies During Grassland Succession. Journal of Ecology. 82. 69-77.

Partidge, I., Middleton, C. and Shaw, K., 1996. Stylos for Better Beef. Queensland Department of Primary Industries. Brisbane.

Pasumarty, S. V., Higuchi., Murata, T. and Matsumura, T., 1995. Influence of Seed Quality on Seedling Growth of White Clover (Trifolium Repens L). Grass and Forage Science. 50. 93-97.

Rossiter, M., 1996. Incidence and Consequences of Inherited Environmental Effects. Annual Review of Ecology and Systematics 27: 451-476.

Rangel, J. H. D. A. and Gardiner, C. P., 1994. Effect of Fire and Heat on Seed Germination of Desmanthus Virgatus Accessions. The Future of Tropical Savannas Symposium. Townsville. Australia. July 19-22. 1994. 1994.43-44.

Schmitt, J. and Antonovics, J., 1986. Experimental Studies of The Evolutionary Significance of Sexual Reproduction III. Maternal and Paternal Effects During Seedling Establishment. Evolution. 40. 817-829.

Sills, G. R. and Nienhuis, J., 1995. Maternal Phenotypic Effects Due to Soil Nutrient Levels and Sink Removal in Arabidopsis Thaliana (Brassicaceae). American Journal of Botany. 82. 491-495.

Skerman, P. J., Cameron, D. G. and Riveros, F., 1988. Tropical Forage Legumes. Second edition. Food and Agriculture Organization of the United Nations. Rome.

Sorennson, C. T., Shelton, H. M. and Austin, M. T., 1994. Seedling Vigour of Some Leucaena Spp: Their Hybrids. Tropical Grasslands, 28, 182-190.

Uller, T., 2008. Developmental Plasticity and The Evolution of Parental Effects. Trends Ecol Evol, 23:432-438.

Williams, E. R., Gunn, B., Reynolds, D. and Westcott, M., 1992. Germination Tests for Small Collections of Acacia Seed. Seed Science and Technology. 20. 321-326.

Wold, J.B. and Wade M.J, 2009. What Are Maternal Effects (and What Are They Not). Philos Trans R Soc B-Biol Sci. 364: 1107-1115. 